\title{
POŠTA
}

TELEKOMUNIKACIE A

ELEKTRONICKÝ OBCHOD

elelsh

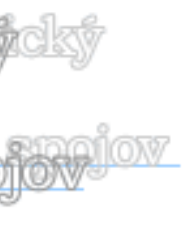

\section{MOŽNOSŤ VIZUALIZÁCIE LOGISTICKÉHO REŤAZCA}

\author{
Juraj Vaculík ${ }^{1}$, Peter Gregáň ${ }^{2}$
}

\section{Úvod}

Ciel’om príspevku je predstavit' návrh vizualizácie logistického ret'azca prostredníctvom jazyka KML. Prvý krok predstavuje získavanie GPS súradníc pomocou bežne dostupnej aplikácie v mobilnom telefóne. Výsledky merania sa zaznamenávajú v aplikácii „MyTracks“, ktorá funguje pod operačným systémom iOS alebo Android. Ciel’om použitia aplikácie je generovanie KML súboru, a následné vybranie súradníc a zapísanie do databázy MySQL.

Pomocou súradníc sa zabezpečuje vizualizácia daného logistického ret’azca $\mathrm{v}$ prostredí Google Maps. Snahou bude poukázat' na praktické využitie navrhovanej aplikácie v praxi. Účel riešenia sa zameriava na sledovanie pohybujúcich sa objektov a vyhodnocovanie ich trás. Webová aplikácia je vytvorená s ciel'om slúžit' ako grafické vizualizačné prostredie pre používatel'a.

\section{Logistika a logistický ret’azec}

Koncept riadenia logistických ret'azcov a sietí, umožňuje naplňat' rýchlo a neustále sa rozvíjajúce prostredie informačných technológií. Nevyhnutnost' komunikovania, kooperácie a zdiel'ania informácii medzi jednotlivými článkami ret’azca je jednoduchšie realizovatel’ná práve prostredníctvom informačných technológii. $Z$ tohto dôvodu sa informačné technológie stali vel'mi dôležité v procese efektívneho riadenia logistického ret’azca.

Výraznejší priebeh je zaznamenaný pri nahradzovaní fyzických procesov v podnikoch elektronickými. Teda informačná technológia je významný faktor, ktorý v budúcnosti, a čoraz viac aj v súčasnosti, ovplyvňuje rast a rozvoj logistiky. Pričom diplomová práca sa z pomedzi informačných technológii hlavne zameriava na službu track and trace. [2] Procesy, ktoré prebiehajú v logistickom ret’azci po smere toku pridávajú hodnotu produktu pre zákazníka. Pri riadení logistických ret'azcov a sieti je dôležité zdiel'anie informácií a prepojenie informačných systémov, pre umožnenie sledovania dopytu a zásob pozdĺž celého logistického ret'azca.

Logistický ret’azec predstavuje množinu prvkov usporiadaných tak, aby vytvárali tok informácií a materiálu potrebných pre dosiahnutie istého ciel’a. Logistický ret’azec má dve stránky:

- Hmotná stránka - zahŕňa premiestňovanie surovín, materiálu, dielcov, nedokončených a dokončených výrobkov, obalov, odpadu, osôb a energie. Hmotná stránka je tiež tvorená osobami, vecami, uchovávaním a premiestňovaním vecí podmieňujúcich uspokojenie konečného zákazníka.

\footnotetext{
${ }^{1}$ doc. Ing. Juraj Vaculík, PhD, vedúci AIDC Lab, Žilinská univerzita v Žiline, fakulta PEDAS, katedra spojov, mail: juvac@fpedas.uniza.sk

${ }^{2}$ bc. Peter Gregáň, Žilinská univerzita v Žiline, fakulta PEDAS, katedra spojov,
} 
- Nehmotná stránka - zahŕňa premiestňovanie informácií a financií, ktoré slúžia $\mathrm{k}$ realizácii hmotného toku. [1]

Procesy, ktoré prebiehajú v logistickom ret’azci po smere toku pridávajú hodnotu pre zákazníka. $\mathrm{Na}$ druhej strane sa však musí dbat' na redukovanie nadbytočných procesov $\mathrm{v}$ logistickom ret’azci, ktoré sa nepodiel'ajú na pridaní hodnoty. Prvky logistického ret’azca sa môžu delit':

- aktívne prvky - prvky, ktoré s pasívnymi prvkami uskutočňujú logistické funkcie a operácie napr. l'udia, zariadenia a technické prostriedky,

- pasívne prvky - prvky, ktoré daným ret’azcom prebiehajú napr. materiál, výrobky, nosiče informácií a iné prvky.

Riadenie logistických ret’azcov a sietí môže byt' označené anglickým pojmom Supply Chain Management, ktorý je známy hlavne v stredoeurópskom prostredí. Logistické funkcie, ktoré sú prepojené a tvoria integrovaný celok, prinášajú výhody v rámci riadiacich, nákladových procesov. Už spomínaná koncepcia riadiacich procesov a sietí SCM, obsahuje v sebe dodávatel'a a zákazníka, čo predstavuje rozdiel oproti klasickému pohl'adu na logistiku. SCM predstavuje jeden celok, ako napr. výroba, obstarávanie, distribúcia, atd'. Dáva prednost' strategickému plánovaniu a rozhodovaniu pred operačným.

SCM predstavuje výhody hlavne pre skladovanie, kde predchádza vytvoreniu vel'kých nákladných zásob medzi jednotlivými partnermi. Pri riadení logistických ret’azcov a sietí je dôležité zdiel'anie informácií a prepojenie informačných systémov, pre umožnenie sledovania dopytu a zásob pozdíž celého logistického ret’azca.

SCM definícia blízko súvisí s definíciami logistiky alebo logistického manažmentu, ale jeho definícia zahrňuje d'aleko širší pojem ako logistický manažment (doprava, riadenie toku, manipulácia s materiálmi, skladovanie, informačný systém, plánovanie, spracovanie objednávok, logistická siet', manažment logistických služieb). K rozš́reniu SCM patria: operácie vo výrobe, koordinácia procesov, predaj, navrhovanie produktov, financie a informačné technológie. Na riadenie vzt’ahov je pritom kladený najväčší dôraz. [2] Medzi informačné technológie, ktoré sa podiel'ajú na riadení logistického ret’azca zarad'ujeme:

- Electronic data interchange (EDI) je systém slúžiaci na výmenu podnikových dokumentov a dát medzi počítačmi. Podnikové dokumenty a dáta sú v elektronickej podobe, v štandardizovanom formáte. Na tvorbe spomínaného štandardizovaného formátu sa podiel'a aj Medzinárodná organizácia pre štandardizáciu (ISO). Elektronická dátová výmena umožňuje rýchly prístup k informáciám, znižuje náklady, znižuje administratívu, zabezpečuje lepšiu komunikáciu, zákaznícky servis. Všetky spomenuté služby elektronickej dátovej výmeny zvyšujú produktivitu. Nevýhody EDI sú: vysoké náklady pri vzniku, nepružnost' a predpoklad, že daný systém je funkčný len v prípade ak je zavedený u všetkých partnerských strán.

- Internet a webové prostredie. Sú to predovšetkým softwarové systémy na webovom princípe. Predstavujú výraznejšie lacnejšiu, prístupnejšiu alternatívu v porovnaní so systémom EDI. Pomocou webového prostredia a internetu môžu byt' podnikové informácie prístupné po celkom svete $\mathrm{v}$ reálnom čase. $\mathrm{V}$ tejto skupine môžeme spomenút' technológiu ako je Extensible Markup Language (XML). XML technológia predstavuje najhospodárnejší variant kvôli možnosti výmeny vel'kého počtu dát. Význam XML počítačového jazyka, je hlavne pre menších výrobcov a poskytovatel'ov služieb, ktorí nemajú dostatočné prostriedky na zavedenie systému elektronickej dátovej výmeny.

- Poskytovanie informácii $\mathrm{v}$ rámci informačných technológií, sa uskutočňuje aj pomocou rádiovej frekvencie a čiarových kódov. V oboch prípadoch sa jedná o záznam na produkte, ktorý môže obsahovat' rôzne typy údajov a tiež môže byt' 
strojovo čítaný. Pri procese identifikácie položky je tak možné zistit' potrebné údaje, tiež je možné ju sledovat' v procese expedície v tzv. track and trace systéme.

Možnost' sledovania postupu zásielky $\mathrm{v}$ systéme založenom na webovom princípe, $\mathrm{v}$ súčasnosti ponúka už väčšina väčších dopravcov a zasielatel'ských spoločností. [2]

\section{Keyhole Markup Language (KML)}

Keyhole Markup Lnaguage (KML) je XML zápis pre vyjadrenie geografických vizualizácií, vrátane anotácií v rámci internetu na dvojrozmerných mapách a trojrozmerných prehliadačoch Zeme. Geografická vizualizácia nezahŕňa len prezentáciu grafických dát, ale aj kontrolu navigácie používatel'a $\mathrm{v}$ zmysle, kam íst' a kam sa pozerat' $Z$ tohto pohl'adu KML dopíña väčšinu existujúcich štandardov OGC, vrátane GML. WFS a WMS. V súčasnej dobe KML 2.2 využíva niektoré prvky geometrie z GML 2.1.2. Medzi tieto prvky patrí: bod, sústava bodov, lineárny prsteň a polygón. Jazyk KML bol vytvorený tvorcami Keyhole, Inc. a nadobudnutý spoločnost'ou Google v roku 2004. KML bol vyvinutý pre prácu s Google Earth, ktorý bol pôvodne pomenovaný Keyhole Earth Viewer. [3]

\section{Štruktúra jazyka KML}

Súbor KML špecifikuje sadu funkcií (značky miesta, obrázky, polygóny, 3D modely, textové popisy, atd’.) pre zobrazenie v mapách, mobilných telefónoch, Google Earth alebo v inom 3D prehliadači Zeme, ktorý dokáže čítat' KML súbor. Každé miesto je vždy určené zemepisnou dížkou, zemepisnou šírkou. Ďalšie údaje môžu vytvárat' špecifickejší pohl'ad a to sú sklon, smer, nadmorská výška, ktoré spolu tvoria "pohl'ad kamery". KML súbor môže obsahovat' také údaje, ktoré nie sú možné zobrazit' v mobilnej aplikácii Google Maps. [3]

Nevyhnutnost' komunikovania, kooperácie a zdiel'ania informácii medzi jednotlivými článkami ret’azca je jednoduchšie realizovatel'ná práve prostredníctvom informačných technológií. $\mathrm{Z}$ tohto dôvodu sa informačné technológie stali vel'mi dôležité $\mathrm{v}$ procese efektívneho riadenia logistického ret’azca. Stále viac prebieha $\mathrm{v}$ podnikoch nahradzovanie fyzických procesov elektronickými. Teda informačná technológia je významný faktor, ktorý v budúcnosti, a čoraz viac aj v súčasnosti, ovplyvňuje rast a rozvoj logistiky.

\section{Aplikácia pre vizualizáciu údajov}

Výsledkom práce je aplikácia, ktorá vizualizuje logistický ret’azec prostredníctvom jazyka KML. Vizualizácia prebieha v navrhnutej webovej aplikácii, do ktorej je implementovaná aplikácia Google Maps API. Konkrétne je to verzia 3, ktorá predstavuje riešenie pre PC a aj pre mobilné zariadenia. Používatel' si bude môct' výslednú aplikáciu pozriet' prostredníctvom webového prehliadača.

Obrázok (obr. 1) popisuje proces získavania údajov, ktorý môžeme rozdelit' do štyroch krokov:

1. záznam trasy pomocou mobilného telefónu s nainštalovanou aplikáciou,

2. export do KML súboru,

3. presun súborov do PC,

4. vizualizácia zaznamenaných súradníc

\section{Získavanie údajov}

Prvou úlohou bolo získanie údajov, aby mohla byt' realizovaná posledná čast', ktorou je návrh webovej aplikácie. 


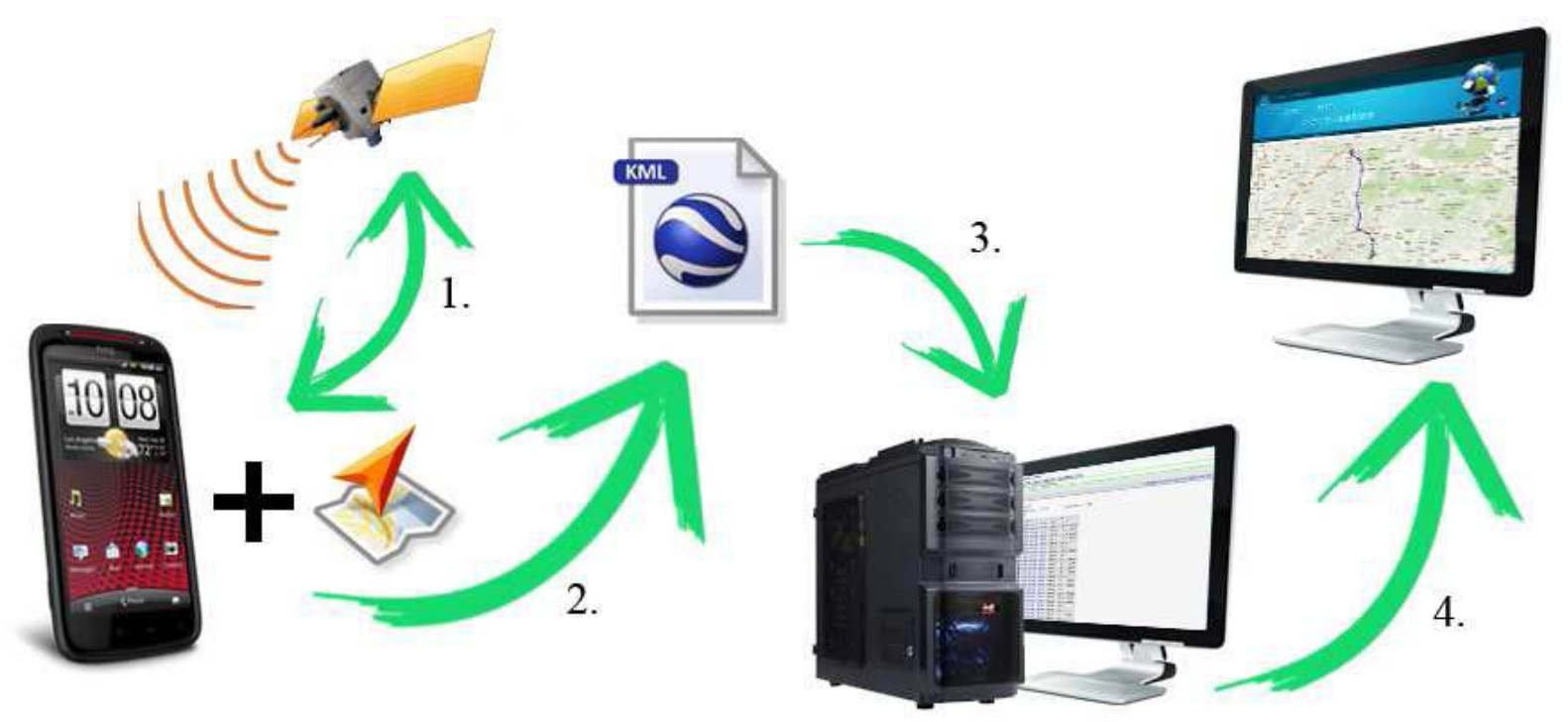

Obrázok 1. Proces získavania údajov (Zdroj: Autor.)

\section{Vytvorenie databázy a naplnenie tabuliek}

Po dokončení procesu získavania údajov, sme vytvorili databázu typu MySQL.

Databázu sme použili na to, aby sme mohli interpretovat' výsledky z KML súboru do aplikácie. Databázu sme vytvorili na lokálnom serveri, prostredníctvom webovej aplikácie „,phpMyAdmin“. Štruktúra databázy s názvom „,KML “ sa skladá z troch tabuliek:

- coordinates,

- krokovac,

- mapa.

Štruktúra tabul'ky „,coordinates“ sa skladá zo štyroch stĺpcov s názvami (id, x, y, z), ktoré sú reprezentované nasledovným významom:

- id - identifikátor, ktorý prideluje novému záznamu unikátne číslo a predstavuje typ auto increment,

- $\quad x, y, z$ - súradnica $x, y$ a z - ovej osi,

V tabul'ke „,coordinates“ sú súradnice jednotlivo zapísané pomocou php skriptu, uvedeného v súbore ,zapis.php“, ktorý má nasledovnú syntax:

$$
\begin{aligned}
& <\text { ?php } \\
& \text { include ('db.php'); } \\
& \text { include ('config.php'); } \\
& \text { if(!empty(\$_POST["coor"])) \{ } \\
& \text { \$suradnicePole = \$_POST['coor']; }
\end{aligned}
$$$$
\$ a="</ \text { coordinates }>\text { "; }
$$$$
\$ b="<\text { coordinates }>\text { "; }
$$$$
\text { \$vyber = str_Replace }(\$ a, \$ b, \$ \text { suradnicePole }) \text {; }
$$$$
\text { \$vypis = explode }("<\text { coordinates }>\text { ",\$vyber }) \text {; }
$$$$
\text { \$suradnicePole = explode(" ",\$vypis[3]); }
$$$$
\$ i=0 \text {; }
$$$$
\text { foreach (\$suradnicePole as \$key }=>\text { \$value) }\{
$$$$
\text { \$suradnica=explode(",",\$value); }
$$$$
\text { if }(\$ i>0) \text { \$hodnoty. =","; }
$$

\$hodnoty="(".\$suradnica[0].",".\$suradnica[1].",".\$suradnica[2].")"; 


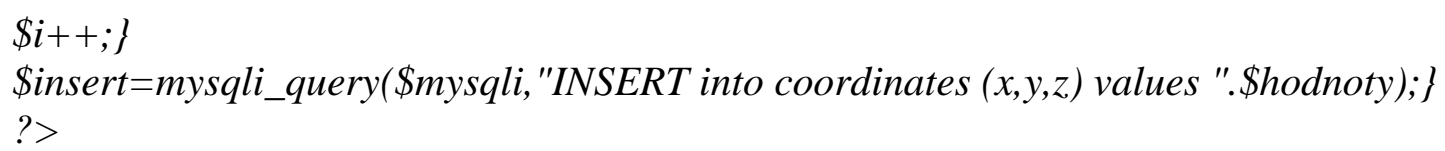

Uvedený script vyberá súradnice z KML súboru, ktoré sú vložené do formulára. Každá súradnica je $\mathrm{z}$ formátového hl'adiska oddelená čiarkou a každý blok súradníc je oddelený medzerou. Script najprv vyberie všetky súradnice a vylúči z nich medzeru. V d’alšom kroku daný výber je vložený do pol'a a následne prebehne cyklus, ktorý odstráni zvyšné čiarky medzi súradnicami. Pričom jednotlivé súradnice sú zapisované do stlípcov v tabul'ke databázy. Štruktúra tabul'ky „,krokovac“ sa skladá z troch stĺpcov s názvami (id, sett, counter), ktoré sú reprezentované nasledovným významom:

- id - identifikátor, ktorý pridel'uje novému záznamu unikátne číslo a predstavuje typ auto increment,

- sett - určuje dížku ret́azca, ktorá bude zobrazená vo vizualizačnej aplikácii ,

- counter - určuje počet krokov, ktorý je závislý na dížke rețazca. Tento vzt́ah môžeme opísat' ako celkovú hodnotu počtu krokov v pomere s dížkou ret’azca, pričom zaokrúhl'ovanie vytvára funkcia „ceil()“. Funkcia „ceil()“, vracia hodnotu zaokrúhleného čísla nahor k najbližšiemu celému číslu.

Ako bolo spomenuté, webová aplikácia je tvorená skriptovacím jazykom PHP, značkovacím jazykom HTML, databázou MySQL a súbormi KML. Pre prácu s KML súbormi v prostredí HTML sme použili javascriptovú aplikáciu Google Maps API v3, ktorú sme implementovali do vytvoreného HTML dokumentu. Nasledujúca syntax nám hovorí o tom ako vyzerá javascript pomocou ktorého je implementovaná Google mapa do webového prehliadača. Syntax:

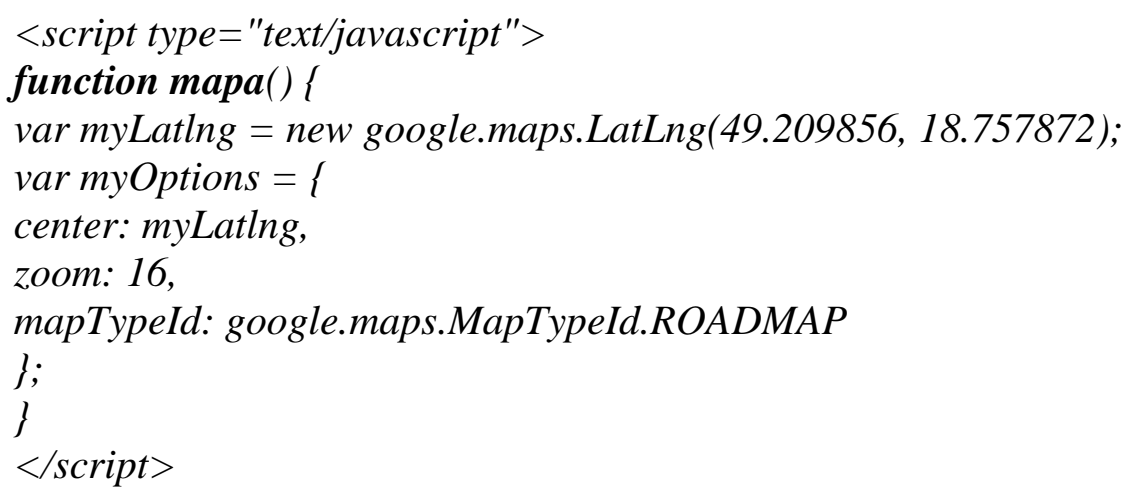

Tento script nám nestačí pre zobrazenie KML súboru, pretože zahŕňa len mapu. Pre zobrazenie tohto súboru potrebujeme do scriptu vložit' ešte jeden príkaz $\mathrm{s}$ adresou, menom serveru a názvom súboru s koncovkou .kml. Je to príkaz ktorý nám načíta KML súbor zo serveru na ktorom je súbor uložený. Z dôvodu, že Google si ukladá užívatel'ské údaje na dlhšiu dobu, je potrebné k súboru pridat' náhodne vygenerovanú premennú, ktorá sa priradí k súboru. Pre náhodné generovanie premennej sme použili funkciu „Math.random()“, ktorá generuje premenné zo zvoleného intervalu hodnôt. Následne súbor a náhodne vygenerovaná premenná sú spoločne načítané. Toto náhodné generovanie je z dôvodu častej úpravy KML súboru a následného posielania na server. Preto pri malej úprave súboru a opätovnom načítaní bez náhodnej premennej, nám zobrazovalo stále neupravený súbor, po dobu približne piatich minút. Náhodná premenná je teda dôležitým nástrojom pre funkčnost' aplikácie. Výsledný script vyzerá takto:

Syntax:

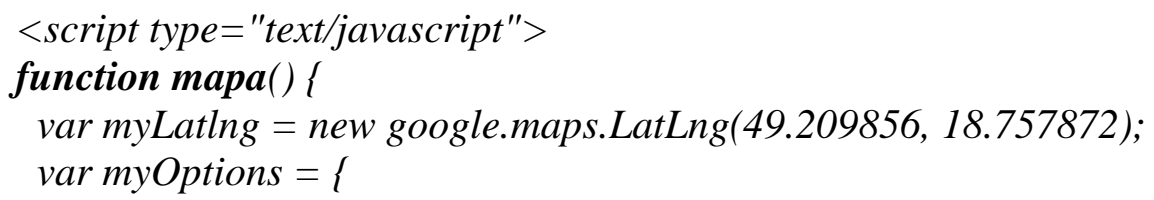




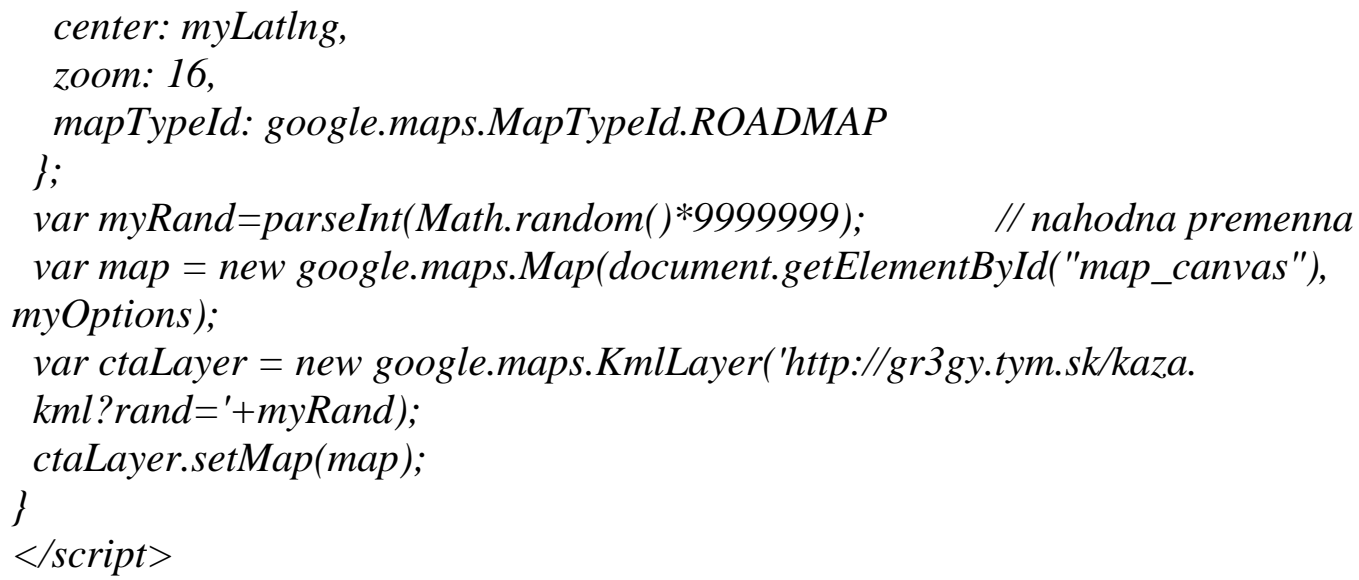

Generovaním náhodnej premennej máme zaručené, že vykonané úpravy v KML súbore môžeme neustále otvárat' v Google Maps pod tým istým názvom, pri kratších intervaloch ako je pät' minút. $\mathrm{K}$ tomu, aby sme ho mohli otvárat' opakovane KML súbor, potrebujeme súbor na tento server poslat'. Odoslanie súboru na server nám zabezpečí php script uložený v súbore „send.php“, ktorý sa pripojí na FTP server a prepíše starý súbor novým. Avšak netreba zabudnút' vytvorit' pasívne pripojenie k serveru, inak naša požiadavka nebude splnená. Po vyriešení problému s posielaním KML súboru na FTP server a jeho zobrazovaním v aplikácii, sme pokračovali vo vytvorení funkčnosti aplikácie. Na vizualizáciu logistického ret’azca sme použili generátor KML súborov. Generátor KML súborov umožňuje vybratie údajov zapísaných v MySQL databáze z tabul’ky „,coordinates“. Pri vybratí údajov prebieha proces, ktorý by sme mohli opísat' nasledovnými krokmi:

- vybratie údajov z jednotlivých stípcov tabul'ky,

- zo súradníc $\mathrm{x}, \mathrm{y}$, z sa vytára pole, v ktorom sa k prvej a druhej hodnote priradí čiarka (tieto hodnoty spoločne vytvárajú jeden bod), medzi jednotlivé body sú priradené medzery,

- takto upravené hodnoty sú vložené do preddefinovanej šablóny KML súboru,

- týmto postupom sme docielili generovanie KML súborov a ich odosielanie na FTP server.

Skončením generovania KML súboru sa nám výsledky súradníc zobrazili v aplikácii Google Maps ako celistvý úsek trate. Aby si používatel' mohol zobrazit' len l'ubovol'nú čast' trate do formulára zvolí počet súradníc, ktorý chce zobrazit'. Stlačením tlačidla ,nastavit”, sme aktualizovali stĺpec „sett“ (hodnoty dížky ret'azca, ktoré sú zobrazené vo vizualizačnej aplikácii) v tabul'ke ,krokovac“.

V d’alšom bode sme navrhli tlačidlo „posun trasy“. Toto tlačidlo nám zaručí vizualizáciu KML súboru, ktoré po kliknutí zobrazí nami zvolenú vel'kost' trasy. Pre zobrazenie d'alších krokov musíme použit' podmienku, ktorá sa bude pýtat' či sa $\mathrm{v}$ uvedenej adrese vykonal predchádzajúci krok. Po stlačení tlačidla „posun trasy“ sa do pol’a \$_GET načíta hodnota kroku z adresy webového prehliadača. Počiatočná hodnota premennej ,step“ sa rovná nule a po stlačení tlačidla „posunu trasy“ sa hodnota inkrementuje, čím zaručíme vykreslenie d’alšieho kroku. Výsledná podmienka má nasledujúcu syntax:

if (!isset(\$_GET['step']) || (isset(\$_GET['step']) \&\& \$_GET['step'] =="'"))

$\$$ step $=0$ else $\$$ step $=\$ \_$GET['step'];

echo $(\$ s t e p+1)$; 

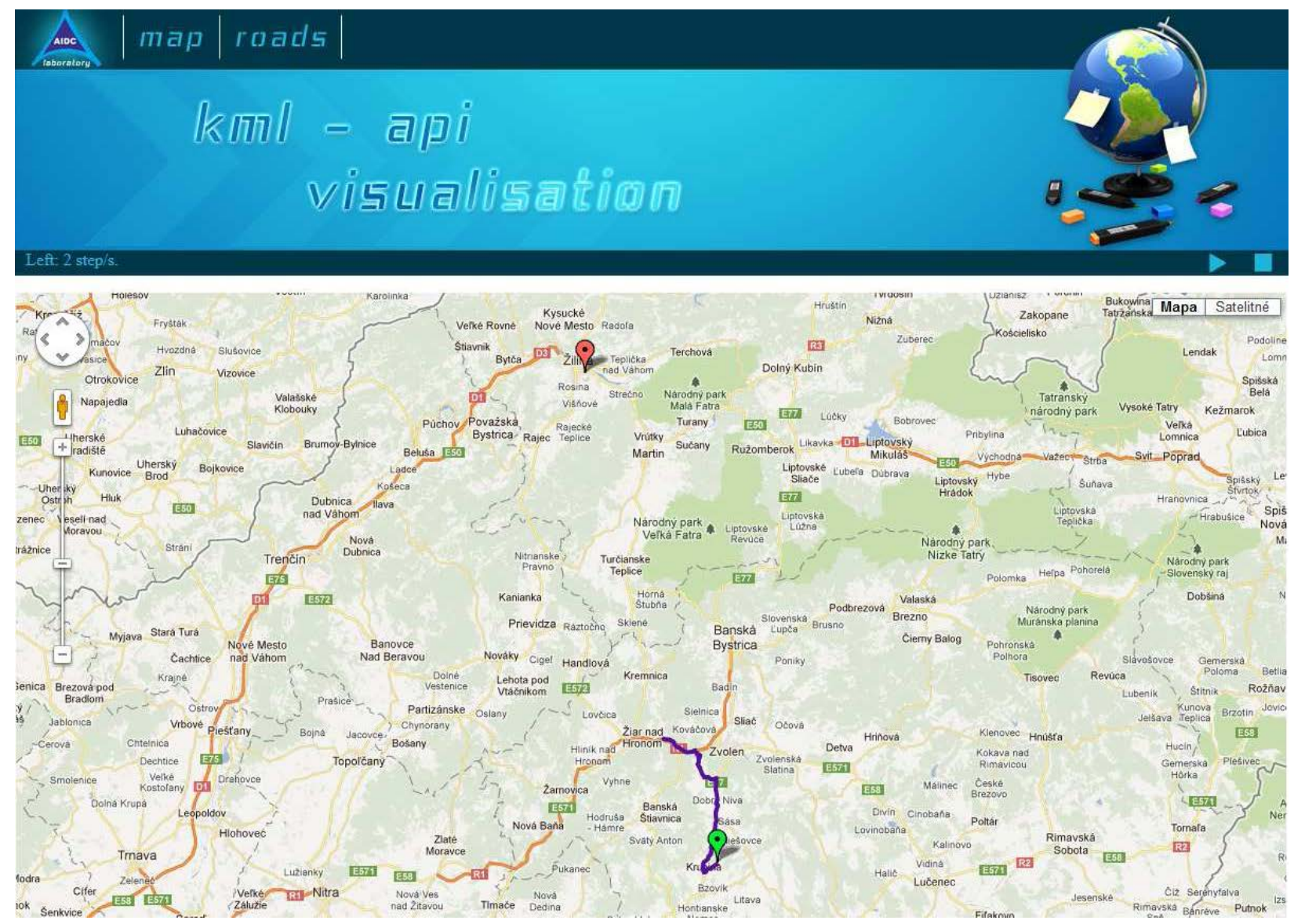

\section{Využitie aplikácie v praxi}

Vytvorená webová aplikácia vizualizácie logistického ret’azca môže tvorit' užitočný základ systémov podporujúcich logistické procesy. Výhody plynúce $\mathrm{z}$ využitia systémov podporujúcich logistické procesy:

- Pri centralizovanom, ale aj decentralizovanom riadení na jednotlivých miestach logistického ret’azca, daný systém umožňuje maximálne prispôsobenie organizácie procesov v spoločnosti.

- Sledovanie pohybov v logistickej sieti. Nástroj, ktorý slúži pre kontrolu a riadenie fyzického a informačného toku a zvyšuje spol'ahlivost' uskutočňovaných operácií.

- Prehl'ad o pohybe zásob v rámci celej siete zaist'uje vyššiu bezpečnost' a prehl'adnost' vo vzt’ahu k zmluvným a legislatívnym podmienkam a nariadeniam.

- Prehl'ad o pohybe tiež zaist'uje dodržiavanie lehôt v rámci životnosti výrobkov.

- Podpora internetovej komunikácie môže znížit' chybovost' v dátach a zaistit' rýchly prenos obchodných dokumentov.

Vizualizácia logistického ret’azca je tiež dobrým nástrojom pre získanie neustáleho prehl'adu o minulom, súčasnom a budúcom pohybe tovaru $\mathrm{v}$ reálnom čase. Umožňuje okamžite reagovat' pri vzniknutých rizikách, mat' možnost' sledovat' rozpory $\mathrm{v}$ rámci siete, vytvorenie bezprostrednej odozvy na požiadavky umiestnenia produktov v logistickom ret'azci.

Konkrétnym príkladom demonštrujúcim využitie aplikácie vizualizácie logistického ret’azca je už spomínaná technológia track and trace (T\&T). Technológiu track-trace, pre sledovanie zásielky, využívajú mnohé zásielkové a dopravné spoločnosti. Umožňujú svojim zákazníkom sledovanie zásielok on-line, získat' údaje o postupe prepravy zásielok v reálnom čase na ceste do miesta určenia. 


\section{Literatúra}

[1] Logistický ret'azec. [online]. [cit. 2012-04-12]. Dostupné na internete:

< http://www.euroekonom.sk/obchod/logistika/logisticky-retazec/>

[2] SERYJ, T. Podniková logistika: Analýza problému a návrh řešení: diplomová práca. Brno: Masarykova univerzita Ekonomicko - správní fakulta, 2011. 64 s.

[3] Popis jazyka KML. [online]. [cit 2012-02-12]. Dostupné na internete:

<https://developers.google.com/kml/documentation/kmlreference>

[4] Google Maps API v3. [online]. [cit 2012-02-12]. Dostupné na internete:

<https://developers.google.com/maps/documentation/javascript/>

[5] Logistika a distribúcia. [online]. [cit. 2012-04-20]. Dostupné internete:

$<$ http://www.u-sluno.eu/logistika.html?setLang=sk>

\section{Grantová podpora}

Príspevok je publikovaný v rámci riešenia projektov VEGA 1/1321/12 Výskum nových trendov v manažmente v období globalizácie.

Tato štúdia/publikácia vznikla vd’aka podpore v rámci operačného programu Výskum a vývoj pre projekt:

Centrum excelentnosti pre systémy a služby inteligentnej dopravy II., ITMS 26220120050 spolufinancovaný zo zdrojov Európskeho fondu regionálneho rozvoja.

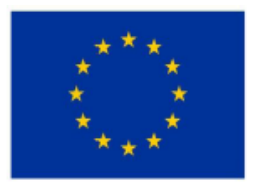

Európska únia

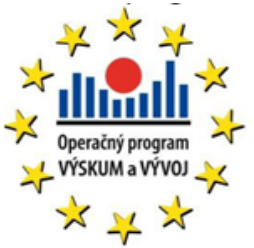

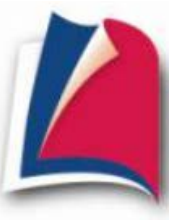

Agentúra

Ministerstva školstva, vedy, výskumu a športu SR pre štrukturálne fondy EÚ

"Podporujeme výskumné aktivity na Slovensku/Projekt je spolufinancovaný zo zdrojov EÚ" 